\title{
Pengaruh Metode Pembelajaran Modul Kontekstual dengan Modifikasi Modul terhadap Kemampuan Pemeriksaan Parameter Fisik Air
}

\author{
The Influence of Contextual Module Learning Methods with Module \\ Modifications on the Ability of Examining Water Physical Parameters
}

\author{
Wiwit Aditama*, \& Zulfikar \\ Politeknik Kesehatan Kementerian Kesehatan Aceh, Aceh, Indonesia \\ widnad78@yahoo.co.id*
}

Naskah diterima tanggal 25/02/2021, direvisi akhir tanggal 24/04/2021, disetujui tanggal 30/04/2021

\begin{abstract}
Abstrak
Jumlah lulusan Sekolah Pembantu Penilik Hygiene (SPPH) yang belum melanjutkan pendidikan di Indonesia sebanyak 2.461 orang dan di Aceh yang terdata pada tahun 2016 yaitu 166 orang. Sanitarian Puskesmas sebagai pelaksana terdepan dari kegiatan kesehatan lingkungan, sehingga harus didukung dengan kompetensi DIII kesehatan lingkungan. Untuk itu, berdasarkan amanat Undang undang maka perlu melanjutkan pendidikan pada program RPL. Akan tetapi dengan usia tua, dengan sistem pembelajaran modul kontekstual maka perlu didukung modul yang lebih praktis dan mudah dipahami. Tujuan Penelitian ini untuk mengetahui pengaruh metode pembelajaran modul dengan modifikasi modul terhadap kemampuan pengambilan sampel air pada peserta program Rekognisi Pembelajaran Lampau (RPL) PRODI D-III Kesehatan Lingkungan Poltekkes Aceh Tahun 2018. Metode pada penelitian ini adalah penelitian analitik dengan populasi adalah seluruh tenaga sanitarian yang sedang mengikuti program RPL sebanyak 90 orang. Analisa data dengan uji statistik uji t berpasangan. Hasil pada penelitian ini yakni tidak terdapat perbedaan yang signifikan antara pengetahuan sebelum dan sesudah pemberian modul kontekstual nilai $\mathrm{p}=0,990$. Ada perbedaan pengetahuan sebelum modul modifikasi - pengetahuan sesudah modul modifikasi dengan nilai $\mathrm{p}=0,000$. Diperlukan gambar dengan detail yang menarik dan terperinci dan lebih baik lagi jika digunakan aplikasi dalam membuat gambar. Produk pengembangan modul hanya teruji pada kelas RPL, sehingga masih perlu diteliti lebih lanjut dalam kelas reguler untuk melihat pengaruh produk.
\end{abstract}

Kata kunci: Modul Kontekstual; Modifikasi Modul; Pengambilan Sampel Air.

\begin{abstract}
The number of School Hygiene Supervisor graduates who have not continued their education in Indonesia is 2,461 people. In Aceh, which was recorded in 2016, there were 166 people. Puskesmas is sanitarian as the leading implementer of environmental health activities, so it must be supported by the competence of DIII in environmental health. For this reason, based on the mandate of the Law, it is necessary to continue education in the RPL program. With a contextual module learning system, old age is necessary to support more practical and easier modules to understand. The purpose of this research is to determine the effect of the module learning method with module modification on the ability of water sampling in participants of the Program Studi Diploma III Past Learning Recognition (RPL) program Environmental Health Polytechnic in Aceh in 2018. This research is analytical research with a population of all sanitarian personnel who are participating in the RPL program as many as 90 people. Analyze data with paired t-test statistical tests. This study shows no significant difference between knowledge before and after giving a contextual module $p$-value $=0.990$. There is a difference in knowledge before the Modification module - Knowledge after modification modules with a value of $p=0,000$. Required images with interesting and detailed details and
\end{abstract}


Volume 21, Nomor 1, 24 - 33

ISSN $1412-565 \mathrm{X}$

April 2021

e-ISSN 2541-4135

even better if you use an application in making images. The module development product is only tested in the RPL class, so it still needs further research in the regular class to see the effect of the product.

Keywords: Contextual Module; Module Modification; Water Sampling. 


\section{PENDAHULUAN}

Hakikat kesehatan lingkungan yaitu keadaan lingkungan yang optimum sehingga berpengaruh positif terhadap terwujudnya status kesehatan yang optimal. Menurut Keputusan Menteri Kepmenkes RI (2006) Nomor 1428/2006, pengawasan kesehatan lingkungan merupakan bagian dari mempertahankan dan meningkatkan kualitas lingkungan yang lebih baik dan bermanfaat bagi umat manusia.

Sanitarian Puskesmas memiliki tugas dan peranan yang penting di Puskesmas yaitu pada upaya-upaya penyehatan lingkungan pemukiman dan perumahan melalui kegiatan sanitasi dasar seperti Penyehatan Air Bersih, Penyehatan Pembuangan Kotoran/Jamban Keluarga, Penyehatan Perumahan dan Lingkungan, Penyehatan Air Buangan, Pengawasan Sanitasi tempat-tempat Umum, Penyehatan Makanan dan minuman, Pengamanan peredaran dan penggunaan Pestisida serta pengendalian pencemaran pada lingkungan baik fisik, kimia dan biologis yang berpengaruh terhadap kesehatan individu maupun masyarakat (Kepmenkes RI, 2006).

Keberhasilan program kesehatan lingkungan didukung oleh tenaga yang kompeten di bidangnya, terutama tenaga sanitarian. Dengan itu demi pelayanan yang baik maka peran tenaga kesehatan menentukan keberhasilan kegiatan kesehatan lingkungan. Banyak faktor yang mempengaruhi baik dari pemerintah, Lembaga non pemerintah, maupun masyarakat itu sendiri.

Sanitarian Puskesmas sebagai pelaksana terdepan dari kegiatan kesehatan lingkungan, kinerjanya tentu mempunyai peran yang cukup besar dalam menentukan keberhasilan kegiatan tersebut. Untuk tercapai keberhasilan tersebut maka Pemerintah telah menetapkan bahwa kualifikasi minimum pendidikan bagi tenaga kesehatan minimal Diploma III. Hal tersebut dituangkan dalam UU No. 36 tahun 2014 tentang Tenaga kesehatan pasal 9 yang menyatakan bahwa tenaga kesehatan menurut data badan kepegawaian daerah (BKN), sampai dengan tahun 2015 masih terdapat sekitar 74.601 tenaga kesehatan yang belum memiliki pendidikan minimal Diploma III, tetapi mempunyai kompetensi sebagai tenaga kesehatan yang diperoleh melalui pengalaman kerja dan/atau pengalaman dalam mengatasi berbagai masalah nyata di lapangan.

Tenaga kesehatan tersebut tidak memiliki pendidikan formal jenjang Diploma III, tetapi keterampilannya sangat dibutuhkan dalam penyelenggaraan pelayanan kesehatan, terutama di daerah terpencil, maka untuk keperluan tersebut perguruan tinggi dapat melaksanakan pengakuan capaian pembelajaran yang mereka peroleh melalui pendidikan formal, nonformal, informal dan pengalaman kerja untuk melanjutkan pendidikan formal dan memperoleh kualifikasi Diploma III melalui Rekognisi Pembelajaran Lampau (RPL) dan harus memiliki kualifikasi minimum Diploma Tiga (Kepmenkes RI, 2006).

Jumlah lulusan Sekolah Pembantu Penilik Hygiene (SPPH) yang belum melanjutkan pendidikan di Indonesia sebanyak 2.461 orang. Di Aceh yang terdata pada tahun 2016 yaitu 166 orang, dan merupakan jumlah lulusan DI terbanyak di Indonesia yang belum melanjutkan pendidikan. Banyak faktor yang mempengaruhi sehingga lulusan SPPH tidak melanjutkan pendidikan. Pelaksanaan kinerja sangat dipengaruhi oleh beberapa faktor yang bersumber dari individu atau pekerjaan sendiri maupun organisasi. Untuk individu sangat dipengaruhi oleh kemampuan dan kompetensi (Aulia \& Sasmita, 2014)

Kompetensi lulusan DIII Kesehatan Lingkungan diantaranya adalah mampu mengoperasikan dan melakukan pengambilan sampel lingkungan baik untuk mengetahui kualitas lingkungan secara fisik, kimia dan mikrobiologi (Kepmenkes RI, 2006). Salah satu kompetensi dalam pengambilan sampel air serta pemeriksaan secara fisik yaitu untuk air sumur, sungai dan air kran (Kepmenkes RI, 2006).

Mahasiswa RPL adalah mahasiswa lulusan Diploma I yang rata -rata di atas 40 tahun. Dengan tahun kelulusan berkisar antara 1992 sampai 1998, umumnya mereka bekerja sebagai sanitarian di Puskesmas atau Rumah Sakit. Akan tetapi karena keterbatasan tenaga banyak sanitarian dialih fungsikan menjadi tenaga manajemen, membantu bagian farmasi 
bahkan berprofesi sebagai supir. Hal ini tentu bertentangan dengan profesi sebenarnya. Sehingga pada saat asessment keterampilan untuk melanjutkan pendidikan Diploma III sesuai amanat UU No. 36 tahun 2014 tentang Tenaga Kesehatan. Umumnya tidak mampu melaksanakan kompetensi dasar terutama dalam hal teknik sampling lingkungan. Dengan alasan lupa atau tidak pernah melakukan lagi atau alatnya berbeda pada saat kuliah SPPH.

Metode pembelajaran RPL adalah dengan modul dan tutorial yang berisi konsep dan teknik praktikum. Akan tetapi karena keterbatasan kemampuan akibat faktor usia maka pada umumnya mengeluh sulit dan tidak sempat membaca dengan modul yang berkisar 60-300 halaman.

Pada hakikatnya penyampaian materi pembelajaran atau proses belajar mengajar merupakan proses komunikasi yaitu proses penyampaian pesan atau pikiran dari seseorang kepada orang lain, penggunaan metode yang tepat akan menjadikan siswa secara efektif mampu menerima pesan yang disampaikan (Sari \& Jusar, 2018).

Salah satu pendukung berhasilnya suatu proses pembelajaran kontekstual di sekolah yaitu dengan adanya bahan ajar. Bahan ajar (learning materials) merupakan seperangkat materi atau substansi pelajaran yang disusun secara runtut dan sistematis serta menampilkan sosok utuh dari kompetensi yang akan dikuasai mahasiswa dalam kegiatan pembelajaran. Salah satu contoh bahan ajar yang dapat mendukung kegiatan pembelajaran kontekstual yaitu modul pembelajaran. Modul adalah salah satu bentuk bahan ajar berbasis cetakan yang dirancang untuk belajar secara mandiri oleh mahasiswa karena itu modul dilengkapi dengan petunjuk untuk belajar sendiri (Arsyad, 2011).

Berdasarkan latar belakang diatas, maka peneliti merancang modul praktikum sederhana yang mudah dipahami dan akan dilakukan penelitian tentang perbedaan pengaruh metode pembelajaran modul dengan modifikasi modul terhadap kemampuan pemeriksaan parameter fisik air pada peserta program Rekognisi Pembelajaran Lampau (RPL) PRODI D-III Kesehatan Lingkungan Poltekkes Aceh Tahun 2018. Apakah ada perbedaan kemampuan pemeriksaan parameter fisik air pada peserta program Rekognisi Pembelajaran Lampau (RPL) PRODI D-III Kesehatan Lingkungan Poltekkes Aceh Tahun 2018 metode pembelajaran modul kontekstual dengan modifikasi modul. Tujuan penelitian ini adalah untuk mengetahui pengaruh metode pembelajaran modul kontekstual terhadap kemampuan pengambilan sampel air kran dan sumur secara bakteriologi pada peserta program Rekognisi Pembelajaran Lampau (RPL) PRODI D-III Kesehatan Lingkungan Poltekkes Aceh Tahun 2018.

Untuk mengetahui pengaruh metode modifikasi modul kontekstual terhadap kemampuan pengambilan sampel air kran dan sumur secara bakteriologi pada peserta program Rekognisi Pembelajaran Lampau (RPL) PRODI D-III Kesehatan Lingkungan Poltekkes Aceh Tahun 2018, dengan tujuan khusus adalah untuk mengetahui pengaruh metode pembelajaran modul dengan modifikasi modul terhadap kemampuan pengambilan sampel air kran dan sumur secara bakteriologi pada peserta program Rekognisi Pembelajaran Lampau (RPL) PRODI D-III Kesehatan Lingkungan Poltekkes Aceh Tahun 2018.

\section{METODE PENELITIAN}

Penelitian ini merupakan metode penelitian Quasi Experiment jenis Nonequivalent control group design. Quasi Experiment yaitu metode penelitian yang digunakan untuk mencari pengaruh perlakuan tertentu terhadap yang lain dalam kondisi yang terkendali (Sugiyono, 2016).

Lokasi penelitian dilakukan di Prodi DIII Kesehatan Lingkungan Poltekkes Kemenkes Aceh. Populasi penelitian ini adalah seluruh peserta RPL Tahun 2018 sebanyak 90 orang. Sampel adalah total populasi yaitu semua populasi dijadikan sampel sebanyak 90 orang., dan dibagi dalam dua kelas, kelas A sebagai kelompok eksperimen dan kelas B sebagai kelompok kontrol, masing-masing berjumlah 45 mahasiswa. Rancangan eksperimen dalam penelitian ini ditunjukkan dalam tabel 1 desain matching pretest-posttest control group design di bawah ini: 


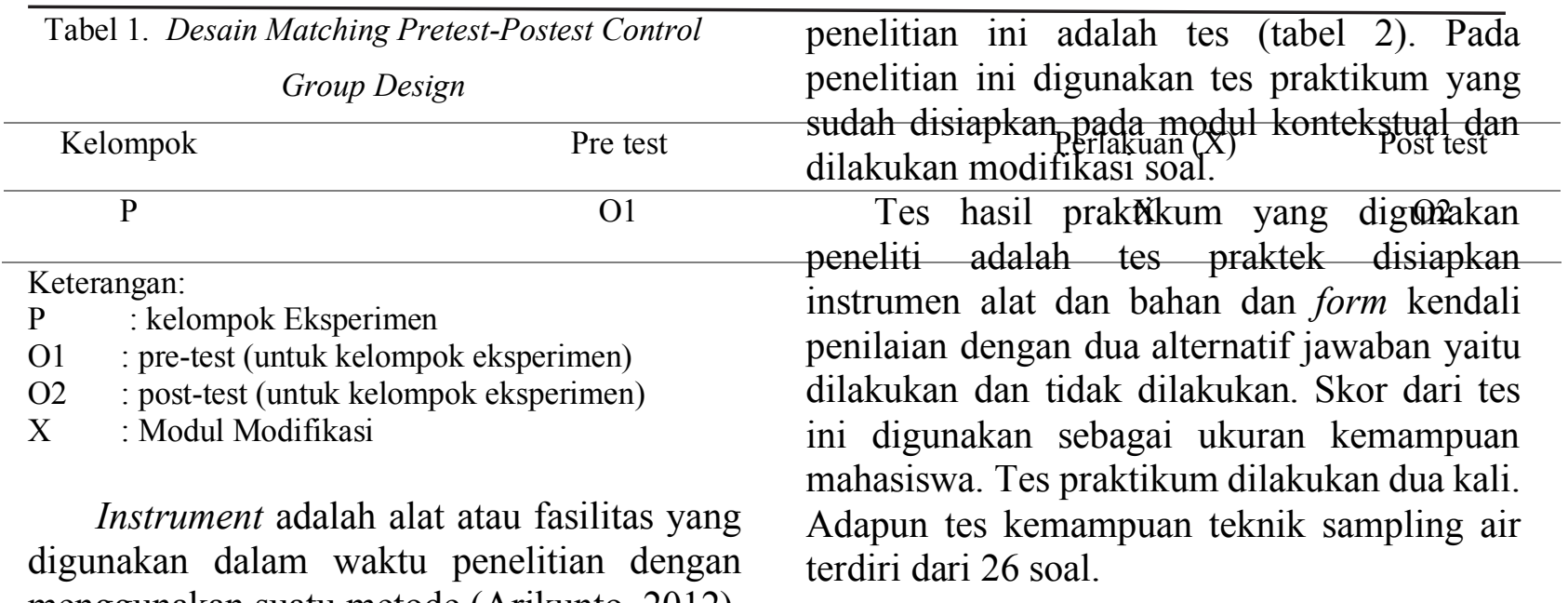
menggunakan suatu metode (Arikunto, 2012).

Instrumen yang digunakan dalam

Tabel 2. Kisi-Kisi Instrumen Pre-test dan Post-test

\begin{tabular}{|c|c|c|c|}
\hline No & Capaian Pembelajaran/kemampuan kerja & Indikator & Mata Kuliah \\
\hline \multirow[t]{7}{*}{1} & \multirow{7}{*}{$\begin{array}{l}\text { Mampu melakukan pengambilan dan } \\
\text { pengiriman sampel serta melakukan } \\
\text { pemeriksaan kualitas Lingkungan secara } \\
\text { akurat dengan pilihan metode yang } \\
\text { sesuai dari beragam pilihan (sesuai } \\
\text { dengan teknik sampling menurut SNI) } \\
\text { pada sumbernya serta intervensi secara } \\
\text { teknis }\end{array}$} & $\begin{array}{l}\text { Persiapan pengambilan sampel } \\
\text { air }\end{array}$ & Teknik Pengambilan sampel \\
\hline & & Pengambilan sampel air & Teknik Pengambilan sampel \\
\hline & & $\begin{array}{l}\text { Pengambilan sampel air untuk } \\
\text { parameter fisika, Pengiriman, } \\
\text { pemeriksaan dan interpretasi }\end{array}$ & Fisika Lingkungan \\
\hline & & hasil pemeriksaan & \\
\hline & & $\begin{array}{l}\text { Pengambilan sampel air untuk } \\
\text { parameter kimia, pengiriman, } \\
\text { pemeriksaan dan interpretasi } \\
\text { hasil pemeriksaan }\end{array}$ & Kimia Lingkungan \\
\hline & & $\begin{array}{l}\text { Pengambilan sampel air untuk } \\
\text { parameter mikrobiologi, } \\
\text { pengiriman, pemeriksaan dan } \\
\text { interpretasi hasil pemeriksaan }\end{array}$ & Mikrobiologi Lingkungan \\
\hline & & $\begin{array}{l}\text { Prinsip persiapan, penentuan } \\
\text { titik dan pengambilan sampel } \\
\text { air }\end{array}$ & Teknik pengambilan Sampel \\
\hline
\end{tabular}

Penyusunan kuesioner menggunakan skala Guttman yaitu karena jawaban dari kuesioner bersifat jelas (tegas) dan konsisten terhadap permasalahan yang ditanyakan. Jawaban dibuat dalam bentuk checklist dengan empat pilihan jawaban. Skor tertinggi bernilai

(2) dan skor terendah (1) (Riduwan, 2004).

\section{HASIL DAN PEMBAHASAN}

Analisa data hasil penelitian dilakukan melalui 3 tahapan yaitu analisis univariat, analisis bivariat dan analisis multivariat. digunakan metode paired samples t-test uji Manova.

\subsection{Hasil}


A. Karakteristik Responden

Karakteristik responden berdasarkan usia dan jenis kelamin adalah sebagaimana pada tabel 3 berikut:

Tabel 3. Distribusi karakteristik responden pada program Rekognisi Pembelajaran Lampau (RPL) PRODI D-III Kesehatan Lingkungan Poltekkes Aceh Tahun 2018.

\begin{tabular}{|c|c|c|c|c|}
\hline $\begin{array}{l}\mathrm{N} \\
\mathrm{O}\end{array}$ & \multicolumn{2}{|c|}{ Karakteristik } & Jumla & $\%$ \\
\hline \multirow[t]{7}{*}{1} & \multirow{7}{*}{ Kontrol } & Jenis Kelamin & \multirow{4}{*}{$\begin{array}{l}12 \\
33\end{array}$} & \multirow{3}{*}{26,66} \\
\hline & & a. Laki - & & \\
\hline & & Laki & & \\
\hline & & $\begin{array}{l}b . \text { Perempu } \\
\text { an }\end{array}$ & & 73,33 \\
\hline & & Usia & & \\
\hline & & a. $>40-50$ & 11 & 24,44 \\
\hline & & $\begin{array}{ll} & \text { thn } \\
\text { b. } & >50 \text { thn }\end{array}$ & & 75,55 \\
\hline \multirow[t]{6}{*}{2} & \multirow{6}{*}{$\begin{array}{l}\text { Kelomp } \\
\text { ok } \\
\text { intervens } \\
\text { i }\end{array}$} & Jenis Kelamin & & \\
\hline & & a. Laki-Laki & 15 & 33,33 \\
\hline & & b. Perempua & 30 & 66,66 \\
\hline & & Usia & & \\
\hline & & a. $>40-50$ & 8 & 17,77 \\
\hline & & b. $>50$ thn & 37 & 82,22 \\
\hline
\end{tabular}

Karakteristik responden berdasarkan hasil diatas adalah pada kelompok perlakuan terdapat 33,3\% responden laki-laki dan usia terbanyak pada golongan umur $>50$ tahun yaitu sebanyak $75,5 \%$ pada kontrol dan $82,22 \%$ pada kelompok perlakuan.

B. Hasil Pengukuran

Hasil penelitian rata -rata nilai keterampilan adalah sebagaimana tabel 4 berikut ini:

Tabel 4. Distribusi nilai hasil keterampilan pada responden pada program Rekognisi Pembelajaran Lampau (RPL) PRODI D-III Kesehatan Lingkungan Poltekkes Aceh Tahun 2018

\begin{tabular}{|c|c|c|c|c|c|}
\hline Variabel & $\mathrm{N}$ & $\begin{array}{l}\text { Nilai } \\
\text { minim } \\
\text { um } \\
\end{array}$ & $\begin{array}{l}\text { Nilai } \\
\text { maksim } \\
\text { um }\end{array}$ & $\begin{array}{l}\text { rata } \\
- \\
\text { rata } \\
\end{array}$ & $\begin{array}{l}\text { Simpan } \\
\text { gan } \\
\text { baku }\end{array}$ \\
\hline $\begin{array}{l}\text { Keteramp } \\
\text { ilan } \\
\text { sebelum } \\
\text { model } \\
\text { kontekstu } \\
\text { al }\end{array}$ & $\begin{array}{l}4 \\
5\end{array}$ & 30,40 & 60,80 & $\begin{array}{l}42 \\
22\end{array}$ & 6,54 \\
\hline $\begin{array}{l}\text { Keteramp } \\
\text { ilan } \\
\text { sesudah } \\
\text { modul }\end{array}$ & $\begin{array}{l}4 \\
5\end{array}$ & 30,40 & 60,80 & $\begin{array}{l}42 \\
98\end{array}$ & 7,23 \\
\hline
\end{tabular}

kontekstu

al

Keteramp

ilan

$\begin{array}{llllll}\text { sebelum } & 4 & 30,40 & 60,80 & 42, & 05\end{array}$

modifikas

i

Keteramp

ilan

$\begin{array}{llllll}\text { sesudah } & 4 & 30,40 & 83,60 & 57, & 25\end{array} \quad 12,24$

modifikas

i 1

Keteramp

ilan

$\begin{array}{llllll}\text { sesudah } & 4 & 45,60 & 87,40 & 63, & 10,05\end{array}$

modifikas

i 2

Pada Tabel 4 terlihat rata - rata nilai keterampilan yang terendah adalah pada keterampilan sebelum diberikan modul modifikasi yaitu dengan nilai 42,05 dan nilai terendah 30,40 dan nilai keterampilan tertinggi 60,80 keterampilan sesudah diberikan modul modifikasi dengan nilai tertinggi 63,33 .

Hasil perhitungan statistik didapatkan data distribusi normal sehingga dapat dilakukan uji t dengan adalah sebagaimana pada tabel 5 berikut ini :

Tabel 5. Distribusi perhitungan statistik pada responden pada Program Rekognisi Pembelajaran Lampau (RPL) PRODI D-III Kesehatan Lingkungan Poltekkes Aceh Tahun 2018

\begin{tabular}{lllll}
\hline Model pembelajaran & CL & t & Nilai \\
& & $95 \%$ & & p \\
\hline Kontrol & Keterampila & $(-$ & 1,354 & 0,18 \\
& $n$ sebelum & $1.891)$ & & 3 \\
& model & $-0,137$ & & \\
& kontekstual - & & & \\
& Keterampila & & & \\
& n sesudah & & & \\
& modul & & & \\
Perlakua & kontekstual & & & \\
n 1 & Keterampila & $(-$ & - & 0,00 \\
& n sebelum & 17.964 & 11,08 & 0 \\
& modul & )$-(-$ & 1 & \\
& modifikasi - 12,435 & & \\
& Ketrampilan & ) & & \\
& sesudah & & & \\
& modul & & & \\
Perlakua & modifikasi 1 & & & \\
n 2 & Keterampila & $(-$ & $-9,447$ & 0,00 \\
& n sesudah & $7,377)-$ & & 0 \\
& modul & $(-$ & & \\
\hline
\end{tabular}




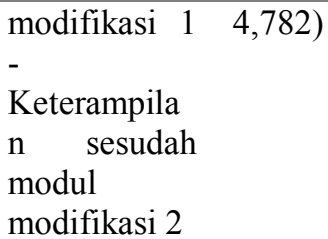

Hasil perhitungan statistik menunjukkan pada kontrol tidak terdapat hubungan antara keterampilan sebelum dan sesudah pemberian modul kontekstual nilai $\mathrm{p}=0,183$ dan hasil keterampilan sebelum modul modifikasi -

Tabel 6. Hasil Uji Perbedaan Keterampilan awal dan hasil uji pertama dan kedua setelah di beri modul modifikasi responden pada Program Rekognisi Pembelajaran Lampau (RPL) PRODI D-III Kesehatan Lingkungan Poltekkes Aceh Tahun 2018

\begin{tabular}{|c|c|c|c|c|c|c|c|c|}
\hline Source & Dependent Va & able & & $\begin{array}{l}\text { Type III Sum } \\
\text { of Squares }\end{array}$ & $\mathrm{df}$ & $\begin{array}{l}\text { Mean } \\
\text { Square }\end{array}$ & $\mathrm{F}$ & Sig. \\
\hline \multirow[t]{2}{*}{$\begin{array}{l}\text { Corrected } \\
\text { Model }\end{array}$} & $\begin{array}{l}\text { Pengetahuan } \\
\text { modifikasi } 1\end{array}$ & sesudah & modul & $3205,211^{\mathrm{a}}$ & 7 & 457,887 & 4,996 & 0,000 \\
\hline & $\begin{array}{l}\text { Pengetahuan } \\
\text { modifikasi } 2\end{array}$ & sesudah & modul & $1960,662^{\mathrm{b}}$ & 7 & 280,095 & 4,167 & 0,002 \\
\hline \multirow[t]{2}{*}{ Intercept } & $\begin{array}{l}\text { Pengetahuan } \\
\text { modifikasi } 1\end{array}$ & sesudah & modul & 74298,148 & 1 & 74298,148 & 810,68 & 0,000 \\
\hline & $\begin{array}{l}\text { Pengetahuan } \\
\text { modifikasi } 2\end{array}$ & sesudah & modul & 88691,032 & 1 & 88691,032 & 1319,56 & 0,000 \\
\hline \multirow[t]{2}{*}{ pre_Inte } & $\begin{array}{l}\text { Pengetahuan } \\
\text { modifikasi } 1\end{array}$ & sesudah & modul & 3205,211 & 7 & 457,887 & 4,996 & 0,000 \\
\hline & $\begin{array}{l}\text { Pengetahuan } \\
\text { modifikasi } 2\end{array}$ & sesudah & modul & $1960 ., 62$ & 7 & 280,095 & 4,167 & 0,002 \\
\hline
\end{tabular}

a. R Squared $=.486$ (Adjusted R Squared $=.389)$

b. $\mathrm{R}$ Squared $=.441($ Adjusted R Squared $=.335)$

Uji dari tabel Multivariate Tests didapat nilai $\mathrm{P}$ value (sig.) $=0.000$ Karena $\mathrm{p}$ value (Sig.) $<0.05$ maka H0 ditolak sehingga dapat disimpulkan bahwa terdapat perbedaan hasil keterampilan sebelum diberi modul modifikasi dengan hasil keterampilan pertama dan tes uji kedua.

Selanjutnya dari tabel Tests of BetweenSubjects Effects. menunjukkan bahwa 1. Hubungan keterampilan antara sebelum pemberian modul modifikasi dengan keterampilan uji 1 memiliki tingkat signifikansi (sig. Y1) $0.000<0.05$. hal ini menunjukkan bahwa terdapat keterampilan antara sebelum pemberian modul modifikasi dengan keterampilan uji 1. 2. Hubungan antara keterampilan antara sebelum pemberian modul modifikasi dengan keterampilan uji 2 (Y2) memiliki signifikansi $0.002<0.05$. Hal ini menunjukkan bahwa terdapat perbedaan hasil keterampilan antara sebelum pemberian modul modifikasi dengan keterampilan uji 2. keterampilan sesudah modul modifikasi 1 dengan nilai $p=0,000$ dan begitu juga keterampilan modul modifikasi 1 ketrampilan sesudah modul modifikasi 2 .

Hasil uji manova antara sebelum diberi modul modifikasi dengan setelah diberi modul dengan hasil pertama dan hasil evaluasi kedua didapatkan hasil pada tabel 6 sebagai berikut:

\subsection{Pembahasan}

Penggunaan modul konseptual nilai ratarata adalah 42. 55 setelah diberi modul. sedangkan setelah diberi modul modifikasi terjadi peningkatan dari nilai 42.055 menjadi 57.25. Dan setelah dilakukan pengulangan evaluasi kedua menjadi 63.33 dari hasil nilai keterampilan pertama. Hal ini menunjukan jika modul modifikasi mampu meningkatkan kemampuan dalam praktikum pengambilan sampel air dibandingkan dengan modul konseptual.

Jika dilihat dari usia peserta RPL 82.2\% diatas 50 tahun. Tentu saja daya ingat juga berbeda dengan mahasiswa reguler. Dan terlebih lagi rata-rata responden 20 tahun lebih tidak pernah belajar kembali.

Ditambah penempatan kerja tidak sesuai dengan bidang ilmu sehingga tidak ada update ilmu baru atau mengulang-ulang pekerjaan lama. Hasil dari perhitungan statistik menunjukan pada kontrol tidak terdapat hubungan antara keterampilan sebelum dan 
sesudah pemberian modul kontekstual nilai $\mathrm{p}$ $=0.990$ dan hasil Keterampilan sebelum modul modifikasi - Ketrampilan sesudah modul modifikasi 1 dengan nilai $p=0.000$ dan begitu juga keterampilan modul modifikasi 1 hingga keterampilan sesudah modul modifikasi 2. Hal ini karena membuktikan dengan modul berbentuk gambar akan lebih mudah dipahami oleh peserta RPL.

Media dalam pembelajaran memiliki fungsi sebagai alat bantu untuk memperjelas pesan yang disampaikan guru. Media juga berfungsi untuk pembelajaran individual dimana kedudukan media sepenuhnya melayani kebutuhan belajar siswa (Prasetyo 2007).

Secara umum media memiliki kegunaan memperjelas pesan agar tidak terlalu verbalistis yaitu (1) Mengatasi keterbatasan ruang; (2) Waktu tenaga dan daya indra; (3) Menimbulkan gairah belajar; (4) Interaksi lebih langsung antara murid dengan sumber belajar; (5) Memungkinkan anak belajar mandiri sesuai dengan bakat dan kemampuan visual; (6) Auditori dan kinestetiknya. memberi rangsangan yang sama; dan (7) Mempersamakan pengalaman dan menimbulkan persepsi yang sama (Ditasari et al., 2013).

\section{Sedangkan}

$$
\text { Prasetyo }
$$

mengemukakan manfaat penggunaan media dalam pembelajaran adalah meningkatkan kualitas hasil belajar siswa dan media dapat menumbuhkan sikap positif siswa terhadap materi dan proses belajar.

Menurut Ditasari et al (2013) Modul merupakan salah satu jenis bahan ajar berbentuk cetak. Media cetak pembelajaran berupa modul merupakan salah satu alat yang sekarang banyak ditempuh dalam proses pembelajaran karena berbagai kondisi pembelajaran saat ini antara lain karakteristik/cara belajar tiap siswa berbeda, kemampuan kognitif tiap siswa yang berbeda terbatasnya waktu pembelajaran di kelas dibandingkan dengan cakupan materi yang harus dikuasai, dan selain itu, modul juga mampu membedakan keterbatasan ruang.

Waktu baik bagi siswa maupun bagi pendidik sendiri artinya pembaca dapat melakukan kegiatan pembelajaran tanpa kehadiran pengajar secara langsung (Ditasari et al., 2013).

Penggunaan modul dalam kegiatan belajar mengajar merupakan salah satu cara untuk menciptakan pembelajaran yang mengutamakan keaktifan siswa. Dalam pembelajaran menggunakan modul. siswa diberi kesempatan belajar menurut cara masing-masing untuk memecahkan masalah yang sedang dihadapi. Pembelajaran dengan modul adalah pendekatan pembelajaran mandiri yang berfokuskan penguasaan keaktifan siswa. Dalam pembelajaran menggunakan modul siswa diberi kesempatan belajar menurut cara masing-masing untuk memecahkan masalah yang sedang dihadapi. (Ditasari et al., 2013; Syam, 2018)

Beberapa penelitian menghasilkan pembelajaran dengan modul adalah pendekatan pembelajaran mandiri yang berfokuskan penguasaan kompetensi dari bahan kajian yang dipelajari siswa dengan waktu tertentu sesuai dengan kondisinya (Aji et al., 2017).

Penelitian lain juga mendukung adalah dimana respon mahasiswa atas penggunaan modul mencapai skor $1.66 \%$ memberi respon positif. bahwa modul praktis dan efektif (Erawanto \& Santoso, 2016).

Dari hasil penelitian dari Modul untuk materi Hukum Kepler sangat cocok apabila disajikan dalam bentuk komik karena komik mengandung aspek grafis yang dapat mengantarkan pembaca pada berbagai realitas yang terkadang sulit dibayangkan. Penelitian menunjukkan bahwa modul dengan teknik komik dapat mempengaruhi hasil belajar siswa.

Penelitian oleh (Puspitorini et al., 2011) menunjukkan bahwa media komik mampu meningkatkan hasil belajar kognitif siswa. Penelitian oleh Enawati dan Sari (2010) menunjukkan bahwa penggunaan media komik dalam pembelajaran memberikan pemahmanan (Agustin et al., 2012). 
IV. KESIMPULAN

Tidak terdapat perbedaan antara keterampilan sebelum dan sesudah pemberian modul kontekstual nilai $\mathrm{p}=0.18$. Ada perbedaan keterampilan sebelum modul modifikasi - Ketrampilan sesudah modul modifikasi dengan nilai $p=0.000$. Diperlukan gambar dengan detail yang menarik dan terperinci dan lebih baik lagi jika digunakan aplikasi dalam membuat gambar. Produk pengembangan modul hanya teruji pada kelas RPL sehingga masih perlu diteliti lebih lanjut dalam kelas reguler untuk melihat pengaruh produk. Produk pengembangan hanya berfokus pada materi pengambilan sampel air sumur dan kran secara bakteriologis. sehingga perlu pengembangan lebih lanjut mengenai pokok bahasan lain atau modul untuk parameter lain dan tempat yang lain. 


\section{DAFTAR PUSTAKA}

Agustin, H. A., Bektiarso, S., \& Bachtiar, R. W. (2012). Pengembangan modul komik fisika pada pokok bahasan hukum kepler di sma kelas xi 1), 168-174.

Aji, S. D., Hudha, M. N., \& Rismawati, A. (2017). Pengembangan Modul Pembelajaran Fisika Berbasis Problem Based Learning untuk Meningkatkan Kemampuan Pemecahan Masalah Fisika. Science Educational Journal, 1(1), 36-51. https://doi.org/10.21070/sej.vli1.830.

Arikunto, S. (2012). Prosedur Penelitian Suatu Pendekatan Praktek. Jakarta: PT Rineka Cipta.

Arsyad, A. (2011). Media Pembelajaran. Jakarta: PT Raja Grafindo Persada.

Aulia, R., \& Sasmita, J. (2014). Pengaruh Pendidikan Dan Pelatihan Kepuasan Kerja dan Kepemimpinan terhadap Kinerja Perawat Rawat Inap Di Rsud Kabupaten Siak. Jurnal Tepak Manajmenen Bisnis, 6(2), 63 - 72.

Ditasari, R., Peniati, E., \& Kasmui. (2013). Pengembangan Modul Pembelajaran IPA Terpadu Berpendekatan Keterampilan Proses Pada Tema Dampak Limbah Rumah Tangga terhadap Lingkungan untuk SMP Kelas VIII. Unnes Science Education Journal, 2(2). DOI 10.15294/USEJ.V2I2.2043.

Enawati, E., \& Sari, H. (2010). Pengaruh Penggunaan Media Komik Terhadap Hasil Belajar Siswa Kelas X Sma Negeri 3 Pontianak Pada Materi Larutan Elektrolit Dan Nonelektrolit. Jurnal Pendidikan Matematika dan IPA, $1(1)$.

Erawanto, U., \& Santoso, E. (2016). Pengembangan Modul Pembelajaran Berbasis Masalah Untuk Membantu Meningkatkan Berpikir Kreatif Mahasiswa. Jurnal Inovasi Pembelajaran, 2(2), 427-436.

Kepmenkes RI. (2006). Kepmenkes No 1428 Tahun 2006, Tentang Pedoman Penyelenggaraan Kesehatan $\begin{array}{llll}\text { Lingkungan Di } & \text { Puskesmas. } & \text { Retrieved }\end{array}$ https://drive.google.com/file/d/1f0RCY_InSwOqeTZ2poubEyZQwFCtBHK

Prasetyo, S. (2007). Pengembangan Pembelajaran Dengan Menggunakan. Multimedia Interaktif Untuk Pembelajaran Yang Berkualitas. Semarang: UNNES.

Puspitorini, R., Prodjosantoso, A. K., Subali, B., \& Jumadi. (2014). Penggunaan Media Komik dalam Pembelajaran IPA untuk Meningkatkan Motivasi dan Hasil Belajar Kognitif dan Afektif. Cakrawala Pendidikan 3, 413-420.

Riduwan. (2004). Dasar-Dasar Statistika. Bandung: Alfa Beta.

Sari, R. T., \& Jusar, I. R. (2018). Analysis of Science Learning Process by Using Learning Module of Character Education Oriented through Quantum Learning Approach. Jurnal Penelitian dab Pembelajaran IPA, 4(1), 1424. https://doi.org/10.30870/jppi.v4i1.2252

Sugiyono. (2016). Metode Penelitian Kuantitatif, Kualitatif dan R\&D. Bandung: PT Alfabet.

Syam, U. (2018). Perbandingan penggunaan modul alur cerita dan modul bergambar terhadap hasil belajar siswa pada materi sistem pernapasan di kelas viii SMP negeri 5 Maiwa Kabupaten Enrekang. 